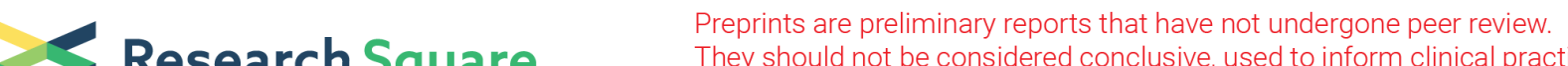 $\begin{array}{ll}\text { Research Square } & \text { They should not be considered conclusive, used to inform clinical practice, } \\ \text { or referenced by the media as validated information. }\end{array}$
}

\section{A Model to Predict the Probability for Intraoperative Blood Transfusion During Lumbar Spinal Stenosis and Femoral Fracture Surgeries in Aged patients}

\section{Zhiyang Nie}

Transfusion Department, Beijing Hospital, National Center of Gerontology; Institute of Geriatric Medicine, Chinese Academy of Medical Sciences, P.R.China.

\section{Wanru Ma}

Transfusion Department, Beijing Hospital, National Center of Gerontology; Institute of Geriatric Medicine, Chinese Academy of Medical Sciences, P.R.China.

Junhua Hu ( $\nabla$ hujunhua3668@bjhmoh.cn )

Transfusion Department, Beijing Hospital, National Center of Gerontology; Institute of Geriatric Medicine, Chinese Academy of Medical Sciences, P.R.China.

\section{Research Article}

Keywords: lumbar spinal stenosis, femoral fracture, aged patients, intraoperative blood transfusion

Posted Date: March 3rd, 2021

DOl: https://doi.org/10.21203/rs.3.rs-258107/v1

License: (1) This work is licensed under a Creative Commons Attribution 4.0 International License. Read Full License 


\section{Abstract}

Background: Lumbar spinal stenosis and femoral fracture are common orthopedic problems in aged patients, and the probability of transfusion of red blood cell products during surgery is relatively high. The goal of this study was to predict the probability of transfusion of allogeneic red blood cells and the volume of blood consumption based on the clinical characteristics of patients before surgery.

Methods: The medical records of 565 patients over 65 years old who underwent posterior lumbar surgery for lumbar spinal stenosis and those of 586 patients over 65 years old receiving surgery for femoral fracture were reviewed. The clinical characteristics of the patients were subjected to multivariate regression analysis. The influence of these characteristics based on the odds ratio of each multivariate risk factor was assessed to predict the probability of intraoperative red blood cell transfusion. Non-linear regression was performed to predict the probability of intraoperative blood transfusion and the volume of blood used for patients with different scores.

Results: The factors that significantly influenced blood use during lumbar spinal stenosis surgery in aged patients $(\mathrm{P}<0.05)$ included age $>75$ years old, body mass index $(\mathrm{BMI})>24$, abnormal coagulation function, preoperative hemoglobin $(\mathrm{Hb}) \leq 110 \mathrm{~g} / \mathrm{L}$, multisegmental lesions of the lumbar spine and secondary lumbar surgery. The factors that significantly influenced blood use during femoral fracture surgery in aged patients $(P<0.05)$ included age $>75$ years old, $B M \mid<19$, abnormal coagulation function, preoperative $\mathrm{Hb} \leq 110 \mathrm{~g} / \mathrm{L}$, administration of antiplatelet drugs (e.g., aspirin, clopidogrel), femoral shaft fracture, and the time from fracture to surgery exceeding $48 \mathrm{~h}$. These factors were introduced into a multiple logistic regression model, and weighted scoring was performed according to their relative risk to establish a risk scoring system to predict the probability. More than $50 \%$ of patients receiving an intraoperative red blood cell transfusion during surgery for lumbar spinal stenosis or femoral fracture scored冈1.

Conclusion: The probability of transfusion of allogeneic red blood cells and the blood volume needed can be predicted preoperatively in aged patients undergoing lumbar spinal stenosis and femoral fracture surgeries. This can reduce the need for blood matching during surgery, allow adjustment of the blood inventory, and ensure safety.

\section{Introduction}

Owing to a deficiency in large evidence-based datasets and the lack of consensus among surgeons, there is a large difference in the probability of intraoperative blood use during surgery for different orthopedic conditions $^{1-2}$. Until now, the focus of most studies on blood use in orthopedic surgery has been on joint replacement ${ }^{1,3}$. However, lumbar spinal stenosis and femoral fracture are common orthopedic conditions in aged patients, and the probability of transfusion of red blood cell products during the perioperative period is relatively high. Finding a suitable blood management strategy for these patients has been a topic of serious attention. Retrospective studies make clear that most perioperative blood management still depends on the experience of clinicians, and different physicians have different blood use practices. 
This does not contribute to the rational perioperative assessment or intraoperative use of blood 4 . Therefore, a blood consumption model was established to preoperatively predict the probability of transfusion of allogeneic red blood cells and the blood volume needed according to the clinical characteristics of the patients. These clinical characteristics will affect the blood loss and hemostasis of patients and the changes of their vital signs during surgery, the length of time in surgery, and the size of the surgical wounds, but cannot predict accidents that may occur during surgery. These clinical features must be observed preoperatively, but not during or after surgery ${ }^{5-7}$. Moreover, the influencing factors for different diseases may vary, so this scoring system is different from other preoperative scoring systems, such as the system proposed by the American Society of Anesthesiologists ${ }^{8}$.

\section{Patients And Methods}

This study was approved by Ethics Committee of Beijing Hospital and conducted in accordance with local regulations and the declaration of Helsinki. Informed consent was obtained from all participants and/or their legal guardians.

Medical records of 565 patients over 65 years old who underwent posterior lumbar surgery for lumbar spinal stenosis and 586 patients over 65 years old receiving surgical treatment for femoral fracture from 2015 to 2018 in the National Center of Gerontology of China were reviewed. Their preoperative clinical data, including age, gender, body mass index, clinical test results and disease characteristics were collected. Actual blood consumption during surgery was defined as the primary outcome measure ${ }^{9}$. These data were sorted using Excel, and analyzed via SPSS 25 (IBM SPSS Statistics for Windows, Version 25.0 Armonk, NY: IBM Corp.) using uni- and multivariate regression models. $P<0.05$ represented a statistically significant difference. The scores of these factors' influences on intraoperative red blood cell infusion were based on the odds ratio (OR) of each multivariate risk factor, and their sensitivity and specificity were evaluated using the receiver operating characteristic (ROC) curve. Non-linear regression was performed to predict the probability of intraoperative blood transfusion and the volume of blood used for patients with different scores.

\section{Results}

The average age of patients with lumbar spinal stenosis was $74.7 \pm 6.4$ years old, and the ratio of males to females was 231:334. The average body mass index (BMI) was 21.46 \pm 2.88 . Red blood cell products were given to $72.1 \%$ of the patients during surgery, with an average amount of $2.1 \mathrm{U} /$ patient.

The average age of patients receiving femoral fracture surgery was $81.5 \pm 8.46$ years old. The ratio of males to females was 170: 416 , with an average BMI of 20.51 \pm 2.93 . Red blood cell products were given to $78.2 \%$ of the patients during surgery, with an average amount of $2.25 \mathrm{U} /$ patient (Table 1 ).

\section{Univariate Analysis of Risk Factors for Intraoperative Blood Transfusion}


Potential risk factors for intraoperative transfusion of allogeneic red blood cells were analyzed to evaluate the risk of intraoperative blood use for these two conditions (Table 2). Characteristics of those who received blood compared to those who didn't during surgery for lumbar spinal stenosis revealed significant $(P<0.05)$ differences between the groups for several demographic and clinical characteristics. Those who received blood were $>75$ years old, with $\mathrm{BMl}>24$, had an abnormal coagulation function and preoperative hemoglobin $(\mathrm{Hb}) \leq 110 \mathrm{~g} / \mathrm{L}$, presented with multi-segmental lesions of the lumbar spine and had a secondary lumbar surgery. Characteristics that significantly influenced the decision for blood use during femoral fracture surgery $(P<0.05)$ included age $>75$ years old, $B M 1<19$, abnormal coagulation function, preoperative $\mathrm{Hb} \leq 110 \mathrm{~g} / \mathrm{L}$, administration of antiplatelet drugs (e.g., aspirin, clopidogrel) before surgery, femoral shaft fracture, and the time from fracture to surgery exceeding $48 \mathrm{~h}$.

\section{Multivariate Regression Model of Risk Factors for Intraoperative Blood Transfusion}

To establish a predictive model of intraoperative blood use, single factors with statistically significant differences were entered into a multiple logistic regression model and scored according to their relative risks, thus constructing a risk scoring system of intraoperative red blood cell transfusion for the two conditions. All parameters mentioned earlier were also significant in the multivariate model. To facilitate its application, we used the smallest odds ratio (about 1.299 for lumbar spinal stenosis surgery and 1.294 for femoral fracture surgery) as the respective score 1 (Table 3). The sensitivity, specificity and area under the ROC curve for lumbar spinal stenosis surgery were $75 \%, 73 \%$ and 0.73 , respectively. The sensitivity, specificity and area under the ROC curve for predicting transfusion during femoral fracture surgery were $71 \%, 76 \%$ and 0.76 , respectively.

\section{Risk score}

The patients were evaluated using the blood use risk scoring system, and the score value, proportion of patients receiving a red blood cell transfusion and the average and median transfusion volume for each patient were obtained (Tables 4 and 5). The results revealed that more than $50 \%$ of patients receiving an intraoperative red blood cell transfusion during surgery for lumbar spinal stenosis or femoral fracture scored $₫ 1$. Non-linear regression was performed to predict the probability of intraoperative blood transfusion and the average volume of blood used for patients with different scores.

To verify the reliability of the scoring system, the proportion of intraoperative blood transfusions and blood consumption of 182 patients with lumbar spinal stenosis and 194 patients with femoral fracture from January to December 2019 were predicted and compared with the actual blood transfusion proportion and blood transfusion volumes (Tables 6 and7). The scores were divided into groups, on the basis of median blood transfusion volume. The model predictions were consistent with the actual surgical values, proving the feasibility of this evaluation method.

\section{Discussion}


Nowadays, anterior and posterior surgical approaches are used for lumbar spinal stenosis. To reduce the variation resulting from different surgical methods, only patients receiving posterior lumbar surgery were selected for the prediction of intraoperative blood use ${ }^{10}$.

Aged patients are less tolerant to anemia, so the probability of transfusion of allogeneic red blood cells increases during surgery ${ }^{9}$. This study demonstrated that the risk of blood use during surgery increases for patients over 75 years old with lumbar spinal stenosis or femoral fracture. The transmission risk of infectious diseases increases from blood transfusion, but usually has a long latency, so the risk of transfusion-related infection is not as important in the evaluation of allogeneic red blood cell transfusion in the older population. The short-term benefits obtained from allogeneic red blood cell transfusion will be more important to the condition of aged patients ${ }^{11-13}$.

$\mathrm{Hb}$ concentration is the most common indication for judging whether red blood cells need to be transfused clinically ${ }^{14}$. Existing transfusion guidelines tend to set an upper threshold for hemoglobin of $10 \mathrm{~g} / \mathrm{dL}$, above which transfusion is not indicated, and a lower hemoglobin threshold of between 6 and 7 $\mathrm{g} / \mathrm{dL}$, below which transfusion is recommended ${ }^{15-18}$. It is difficult to obtain this indicator in time during surgery. Otherwise, the amount of blood used can be greatly affected by intraoperative bleeding and anesthesia. This analysis showed that preoperative anemia in patients with $\mathrm{Hb} \leq 110 \mathrm{~g} / \mathrm{L}$ increased the probability of blood use during surgery, which is consistent with the conclusions of some previous studies $^{9,19}$. However, $\mathrm{Hb}$ concentration itself does not fully represent the tissue oxygen supply of patients ${ }^{20-22}$. Increasingly more studies have illustrated that different patients have a different tolerance to anemia, which also causes a significant difference in the probability of clinical blood use. The results of this study illustrated that the decrease of platelet count preoperatively does not affect blood use during surgery. In this study, patients' platelet data were normally distributed according to the KolmogorovSmirnov test $(P>0.05)$. However, there were few samples with decreased platelet counts (23 in 1151 patients), which may lead to the statistical deviation. In addition, it has been discovered through clinical work that many patients who have no abnormality or a slight abnormality of prothrombin time or activated partial thromboplastin time in a routine coagulation examination actually have coagulation dysfunction ${ }^{23}$. In recent years, it has been found that a thromboelastogram examination may be more diagnostic than a coagulation function examination. A thromboelastogram can predict the obstruction of coagulation function and the need for massive blood transfusion through dynamic evaluation of blood clot formation, blood clot strength and the blood clot dissolution process ${ }^{24-27}$.

$\mathrm{BMI}$ creates a different calculation for intraoperative blood use in different conditions. Low body weight increases the probability of intraoperative blood use in aged patients with femoral fracture, which may be due to the relatively small whole body blood volume of low body weight patients. Perioperative bleeding has a great influence on whole body blood volume. Low-weight patients have less subcutaneous fat, which is not conducive to local hemostasis and will lead to increased hidden blood loss ${ }^{9,28-29}$. On the contrary, overweight patients have a greater probability of blood use during surgery for lumbar spinal stenosis in aged patients. Being overweight or obesity increases the burden on the lumbar spine, so 
overweight patients have serious lumbar lesions or multi-level lesions that indirectly lead to a rise in the probability of blood use during surgery. Further, the central and peripheral venous pressures of patients are usually reduced by anesthesia during spinal surgery, which reduces the bleeding of surgical wounds. The cardiopulmonary compliance of obese patients decreases, and higher ventilation pressure is needed to overcome the low cardiopulmonary compliance, which gives rise to an increase of venous pressure and more bleeding ${ }^{30-31}$.

Aged patients increasingly are taking aspirin, clopidogrel or other anti-platelet aggregation drugs to reduce the risk of cardiovascular and thrombotic events, and many patients will take them during the perioperative period ${ }^{32-33}$. It is necessary to weigh the increased risk of perioperative bleeding caused by continuous use of these drugs and the increased risk of thromboembolic events after withdrawal ${ }^{34-37}$. According to this analysis, patients with femoral fracture who took these antiplatelet aggregation drugs for a long time before surgery had an increased probability of blood transfusion during surgery, but the relative risk was not high. However, most surgeries for lumbar spinal stenosis are elective. Patients who have taken antiplatelet aggregation drugs for a long time should stop taking the drugs for more than seven days before surgery, thus reducing the influence of these drugs on intraoperative bleeding ${ }^{38-40}$.

Interestingly, the results of this study illustrated that patients with chronic diseases such as coronary heart disease, diabetes, hypertension or renal insufficiency have no increased risk of blood use during lumbar spinal stenosis or femoral fracture surgery. This may be because these blood transfusion decisions are determined by the experience of clinicians, who generally set a higher threshold for perioperative blood transfusion in the elderly and are more inclined to use red blood cell products during surgery. Currently, the internationally recognized restrictive blood transfusion strategy usually sets the blood transfusion threshold at $80 \mathrm{~g} / \mathrm{L}$ for perioperative patients ${ }^{41-42}$, and suggests that there is no need to relax the blood transfusion threshold for patients with a history of coronary heart disease $\mathrm{e}^{2,43-44}$. However, some studies have established that the survival time of patients with existing heart diseases tends to decrease in the restricted blood transfusion strategy group, implying that critically ill patients with heart and vascular diseases may benefit from higher $\mathrm{Hb}_{\text {levels }}{ }^{45}$.

Different factors affecting blood use during surgery must be considered for different conditions ${ }^{46}$. Lumbar spinal stenosis in most aged patients is caused by degenerative diseases or long-term strain, so there is a high probability that two or more vertebral segments will be affected ${ }^{30}$. If multi-segment surgery is performed at the same time, the wound will be larger than that of patients with single-segment lesions, the amount of bleeding will increase, and the probability of red blood cell transfusion will increase. Previous studies have shown that if multiple segments at the same site are operated separately, this will increase intraoperative blood loss, which is consistent with our analysis ${ }^{47-49}$. Femoral shaft fractures are mostly caused by severe trauma, and the amount of bleeding can reach $1000-1500 \mathrm{~mL}$. If it is an open or comminuted fracture or a fracture of the distal $1 / 3$ the of femur, it is easy to puncture the popliteal artery and vein. The amount of bleeding may be greater because the blood vessel is located posterior to the fracture site, and the distal end of the fracture often is angled backward towards these vessels. If it is a 
closed fracture of the femur, the recessive blood loss may far exceed the dominant blood loss. Therefore, if there is a long time between the fracture and the surgery, the Hb concentration will decline gradually, which will markedly increase the probability for red blood cell infusion during surgery ${ }^{50}$. Unfortunately, there was no detailed record of the amount of time between fracture occurring and the patient being treated in the emergency room, as this could translate to dehydration and affect the initial $\mathrm{Hb}$ as well. Therefore, the clinical information of the patients we analyzed was the one closest to the time of surgery to minimize the impact of the above factors on the results of the study.

This research has several limitations. The data analyzed in this study were retrospectively extracted from clinical medical records, so the detection time points of some test results were not uniform. The records of past medical history of some patients may not be completely consistent with the actual situation. Moreover, the blood transfusion treatment decisions made for these patients were not based on fixed guidelines, but on the judgment of different surgeons, so there is some variation ${ }^{44,51}$. In addition, the population analyzed in this study was from a single department of a single medical institution, and the number of cases with complete clinical case data was small, so the statistical power is limited. This predictive model needs to be tested and improved in a larger and more diverse population.

\section{Conclusion}

Routine preoperative blood preparation is required for lumbar spine and femoral fracture surgeries in aged patients. The probability of transfusion of allogeneic red blood cells and the blood volume needed can be predicted preoperatively in aged patients undergoing lumbar spinal stenosis or femoral fracture surgeries using our scoring system. The cross-matching test should be carried out preoperatively for lumbar spinal stenosis patients with a blood risk score $\mathbb{1}$, as well as femoral fracture patients. The crossmatching blood volume was based on the score, which can effectively reduce the workload of blood matching during surgery, allow adjustment of the blood inventory, and ensure safety.

\section{List Of Abbreviations}

$\mathrm{OR}=$ odds ratio

$\mathrm{ROC}=$ receiver operating characteristic

$\mathrm{BMI}=$ body mass index

$\mathrm{Hb}=$ hemoglobin

$\mathrm{FIB}=$ fibrinogen

$\mathrm{PT}=$ prothrombin time

APTT $=$ activated partial thromboplastin time 


\section{Declarations}

\section{Ethics approval and consent to participate}

The study was approved by Ethics Committee of Beijing Hospital and carries the study number 2020BJYYEC-277-02. The study was conducted in accordance with local regulations and the declaration of Helsinki.

Consent for publication Not applicable

\section{Availability of data and materials}

The datasets used and/or analysed during the current study are available from the corresponding author on reasonable request.

\section{Competing interests}

The authors declare that they have no competing interests.

Funding None.

\section{Authors' contributions}

Dr. Hu contributed to the conception of the study and helped perform the analysis with constructive discussions;

Dr. Nie contributed significantly to the data extraction from the medical charts and performed the data analyses and wrote the manuscript.;

Dr. Ma contributed to analysis and manuscript preparation;

Acknowledgements: The authors would like to express their gratitude to EditSprings (https://www.editsprings.com/) for the expert linguistic services provided.

\section{References}

1. Barr P J , Donnelly M , Cardwell C , et al. Drivers of Transfusion Decision Making and Quality of the Evidence in Orthopedic Surgery: A Systematic Review of the Literature[J]. Transfusion Medicine Reviews, 2011, 25(4):304-316.e6.

2. Ponnusamy K E, Kim T J , Khanuja H S . Perioperative Blood Transfusions in Orthopaedic Surgery[J]. Journal of Bone \& Joint Surgery American Volume, 2014, 96(21):1836.

3. Burns K A , Robbins L M , Lemarr A R, et al. Estimated blood loss and anemia predict transfusion after total shoulder arthroplasty: a retrospective cohort study[J]. JSES Open Access, 2019, 3(4). 
4. Tinmouth A: Reducing the amount of blood transfused by changing clinicians' transfusion practices. Transfusion 47 (2 Suppl):132S-136S, 2007.

5. Chee YL, Crawford JC, Watson HG, Greaves M. Guidelines on the assessment of bleeding risk prior to surgery or invasive procedures. British Committee for Standards in Haematology. $\mathrm{Br} \mathrm{J}$ Haematol 2008; 140: 496-504.

6. Shah A, Palmer A J R, Klein A A . Strategies to minimize intraoperative blood loss during major surgery[J]. British Journal of Surgery, 2020, 107(2).

7. Torres-Claramunt, R., Ramírez, M., López-Soques, M. et al.Predictors of blood transfusion in patients undergoing elective surgery for degenerative conditions of the spine. Arch Orthop Trauma Surg 132, 1393-1398 (2012). https://doi.org/10.1007/s00402-012-1563-y

8. Shah A, Stanworth SJ, McKechnie S. Evidence and triggers for the transfusion of blood and blood products. Anaesthesia 2015; 70: 10-19.

9. Khanna MP, Hebert PC, Fergusson DA: Review of the clinical practice literature on patient characteristics associated with perioperative allogeneic red blood cell transfusion. Transfus Med Rev 17:110-119, 2003.

10. Bible JE, Mirza M, Knaub MA. Blood-loss management in spine surgery. J Am Acad Orthop Surg. 2018;26:35-44.

11. American Society of Anesthesiologists Task Force on Perioperative Blood Transfusion and Adjuvant Therapies: Practice guidelines for perioperative blood transfusion and adjuvant therapies: an updated report by the American Society of Anesthesiologists Task Force on Perioperative Blood Transfusion and Adjuvant Therapies. Anesthesiology 105:198-208, 2006.

12. Hardy JF, Bélisle S: Erythrocyte transfusion: Friend or foe? Can J Anesth 48:R1-R7, 2001.

13. Bolton-Maggs PH, Murphy MF: Blood transfusion. Arch Dis Child 89:4-7, 2004.

14. Bittencour t R, Costa J, Lobo JE, Aguiar FC. Consciously transfusion of blood products. Systematic review of indicative factors for blood components infusion's trigger. Rev Bras Anestesiol 2012; 62: 402-10.

15. Carson J L , Guyatt G , Heddle N M , et al. Clinical Practice Guidelines From the AABB: Red Blood Cell Transfusion Thresholds and Storage[J]. JAMA The Journal of the American Medical Association, 2016, 316(19):2025.

16. National Institute for Health and Clinical Excellence (NICE) guideline: Blood ransfusion, 2015,

17. Foss NB, Kristensen MT, Jensen PS, et al: The effects of liberal versus restrictive transfusion thresholds on ambulation after hip fracture surgery. Transfusion 49:227-234, 2009.

18. Tobian A A R , Heddle N M , Wiegmann T L , et al. Red blood cell transfusion: 2016 clinical practice guidelines from AABB[J]. Transfusion, 2016, 56(10):2627-2630.

19. Munting KE, Klein AA. Optimisation of pre-operative anaemia in patients before elective major surgery - why, who, when and how? Anaesthesia 2019; 74(Suppl 1): 49-57. 
20. Murphy GJ, Reeves BC, Rogers CA, et al: Increased mortality, postoperative morbidity, and cost after red blood cell transfusion in patients having cardiac surgery. Circulation 116:2544-2552, 2007.

21. Finch CA, Lenfant C. Oxygen transport in man. N Engl J Med 1972; 286: 407-15.

22. Colleen, Koch $\mathrm{G}, \mathrm{MD}$, et al. Tolerating anemia: taking aim at the right target before pulling the transfusion trigger[J]. Transfusion, 2014.

23. Chee YL, Greaves M. Role of coagulation testing in predicting bleeding risk. Hematol J. 2003;4:373378.

24. Cesarman-Maus G, Hajjar KA. Molecular mechanisms of fibrinolysis. Br J Haematol 2005; 129: 307321.

25. Ross, Davenport. Pathogenesis of acute traumatic coagulopathy[J]. Transfusion, 2013.

26. Naik BI, Pajewski TN, Bogdonoff DI, et al. Rotational thromboelastometry-guided blood product management in major spine surgery. J Neurosurg Spine. 2015;23:239-249.

27. Shen L, Tabaie S, Ivascu N. Viscoelastic testing inside and beyond the operating room. J Thorac Dis. 2017;9(suppl 4):S299-S308.

28. Salido JA, Marin LA, Gomez LA, et al: Preoperative hemoglobin levels and the need for transfusion after prosthetic hip and knee surgery: Analysis of predictive factors. J Bone Joint Surg Am 84:216220, 2002.

29. Walsh M, Preston C, Bong M, et al: Relative risk factors for requirement of blood transfusion after total hip arthroplasty. J Arthroplasty 22:1162-1167, 2007.

30. Hu SS. Blood loss in adult spinal surgery. Eur Spine J. 2004; 13(suppl 1):S3-S5.

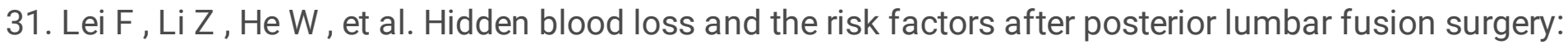
A retrospective study[J]. Medicine, 2020, 99(19):e20103.

32. Van Hecken A, Schwartz JI, Depre M, et al. Comparative inhibitory activity of rofecoxib, meloxicam, diclofenac, ibuprofen, and naproxen on COX-2 versus COX-1 in healthy volunteers. J Clin Pharmacol. 2000;40:1109-1120.

33. Baschera D, Oberle J, Grubhofer F, Schmid SL. Perioperative use of anticoagulant and plateletinhibiting medications for elective spine surgery: results of a nationwide survey. J Neurol Surg A Cent Eur Neurosurg. 2018;79:398-407.

34. van Veen JJ, Makris M. Management of peri-operative anti-thrombotic therapy. Anaesthesia 2015; 70(Suppl 1): 58-67.

35. Keeling D, Tait RC, Watson H; British Committee of Standards for Haematology. Peri-operative management of anticoagulation and antiplatelet therapy. Br J Haematol 2016; 175: 602-613.

36. Levine GN, Bates ER, Bittl JA, Brindis RG, Fihn SD, Fleisher LA et al. 2016 ACC/AHA guideline focused update on duration of dual antiplatelet therapy in patients with coronary artery disease: a report of the American College of Cardiology/American Heart Association Task Force on Clinical Practice Guidelines. J Am Coll Cardiol 2016; 68: 1082-1115. 
37. Douketis JD, Hasselblad V, Ortel TL. Bridging anticoagulation in patients with atrial fibrillation. N Engl J Med 2016; 374: 93-94.

38. Pauyo T, Verma N, Marwan Y, Aoude A, Khashan M, Weber MH. Canadian Consensus for the prevention of blood loss in spine surgery. Spine (Phila Pa 1976). 2017;42:E50-E55.

39. Goes R, Muskens IS, Smith TR, Mekary RA, Broekman MLD, Moojen WA. Risk of aspirin continuation in spinal surgery: a systematic review and meta-analysis. Spine J. 2017;17: 1939-1946.

40. Yoram,Anekstein,Eran,Tamir,Nahum,Halperin,Yigal,Mirovsky.Aspirin therapy and bleeding during proximal femoral fracture surgery.[J].Clinical orthopaedics and related research,2004,(418):205-8.

41. British Committee for Standards in Haematology (BCSH). Guideline on the administration of blood components. http:// www.bcshguidelines.com/documents/BCSH_Blood_Admin_-addendum_August_2012.pdf (accessed Sept 25, 2012).

42. Australasian Society of Blood Transfusion. Clinical practice guidelines: appropriate use of red blood cells. http://www.nhmrc. health.gov.au (accessed Aug 20, 2012).

43. Carson JL, Terrin ML, Noveck $\mathrm{H}$, et al. Liberal or restrictive transfusion in high-risk patients after hip surgery. N Engl J Med 2011; 365: 2453-62.

44. Aslam, Ejaz, Gaya, et al. Identifying Variations in Blood Use Based on Hemoglobin Transfusion Trigger and Target among Hepatopancreaticobiliary Surgeons[J]. Journal of the American College of Surgeons, 2014, 219(2):217-228.

45. Wu WC, Rathore SS, Wang Y, Radford MJ, Krumholz HM. Blood transfusion in elderly patients with acute myocardial infarction. N Engl J Med 2001; 345: 1230-36.

46. Franchini M, Marano G, Veropalumbo E, et al. Patient Blood Management: a revolutionary approach to transfusion medicine. Blood Transfus 2019; 17: 191-5.

47. Feagan BG, Wong CJ, Lau CY, et al: Transfusion practice in elective orthopaedic surgery. Transfus Med 11:87-95, 2001.

48. Hatzidakis AM, Mendlick RM, McKillip T, et al. Preoperative autologous donation for total joint arthroplasty. An analysis of risk factors for allogenic transfusion. J Bone Joint Surg Am 2000;82:89100.

49. Borghi B, Casati A: Incidence and risk factors for allogenic blood transfusion during major joint replacement using an integrated autotransfusion regimen. The Rizzoli Study Group on Orthopaedic Anaesthesia. Eur J Anaesthesiol 17:411-417, 2000.

50. Gul A, Sambandam S, Shanbhag V, et al: Transfusion requirements in hip fractures: Analysis of predictive factors. EJOST 17:71-75, 2007.

51. Salem-Schatz SR, Avorn J, Soumerai SB: Influence of clinical knowledge, organizational context, and practice style on transfusion decision making. Implications for practice change strategies. JAMA 264:476-483, 1990.

\section{Tables}


Table 1. Basic data and clinical characteristics of patients

\begin{tabular}{|c|c|c|c|}
\hline Lumbar spinal stenosis & & Femoral fracture & \\
\hline Age $(y)$ & $74.7 \pm 6.4$ & Age $(y)$ & $81.5 \pm 8.46$ \\
\hline $\operatorname{Sex}(M: F)$ & 231: 334 & $\operatorname{Sex}(M: F)$ & 170: 416 \\
\hline BMI & $21.46 \pm 2.88$ & BMI & $20.51 \pm 2.93$ \\
\hline Comorbidities & $124(22 \%)$ & Comorbidities & $86(14.7 \%)$ \\
\hline $\begin{array}{l}\text { Preoperative hemoglobin }(\mathrm{Hb} \text {, } \\
\mathrm{g} / \mathrm{L})\end{array}$ & $128.2 \pm 14.87$ & Preoperative $\mathrm{Hb}(\mathrm{g} / \mathrm{L})$ & $112 \pm 18.33$ \\
\hline $\begin{array}{l}\text { Preoperative platelet count } \\
\left(\times 10^{9} / \mathrm{L}\right)\end{array}$ & $205.2 \pm 53.87$ & $\begin{array}{l}\text { Preoperative platelet count } \\
\left(\times 10^{9} / \mathrm{L}\right)\end{array}$ & $205.1 \pm 75.96$ \\
\hline Abnormal coagulation function & $52(9.2 \%)$ & Abnormal coagulation function & $49(8.4 \%)$ \\
\hline $\begin{array}{l}\text { Administration of antiplatelet } \\
\text { drugs }\end{array}$ & $185(32.7 \%)$ & $\begin{array}{l}\text { Administration of antiplatelet } \\
\text { drugs }\end{array}$ & $239(40.8 \%)$ \\
\hline Secondary operation & $35(6.2 \%)$ & $\begin{array}{l}\text { Time from fracture to operation } \\
\text { (h) }\end{array}$ & $78.5 \pm 35.7$ \\
\hline \multirow{5}{*}{$\begin{array}{l}\text { Segments of lesions (single: } \\
\text { multiple) }\end{array}$} & 445: 120 & Fracture site & \\
\hline & & Fracture in the shaft of femur & $74(12.6 \%)$ \\
\hline & & $\begin{array}{l}\text { Subtrochanteric fracture of } \\
\text { femur }\end{array}$ & 197 (33.6\%) \\
\hline & & $\begin{array}{l}\text { Intertrochanteric fracture of } \\
\text { femur }\end{array}$ & $26(4.4 \%)$ \\
\hline & & Neck of femur & $289(49.3 \%)$ \\
\hline
\end{tabular}

Table 2. Analysis of risk factors for intraoperative transfusion of allogeneic red blood cells 


\begin{tabular}{|c|c|c|c|}
\hline Disease & Risk factor & $P$ & $\begin{array}{l}\text { Odds } \\
\text { ratio(95\% } \\
\text { Cl) }\end{array}$ \\
\hline \multirow[t]{12}{*}{$\begin{array}{l}\text { Lumbar } \\
\text { spinal } \\
\text { stenosis }\end{array}$} & Age $>75$ & 0.00035 & $\begin{array}{l}1.302 \\
\rrbracket 1.109- \\
1.424 \rrbracket\end{array}$ \\
\hline & Gender & 0.355 & $\begin{array}{l}1.162 \\
\otimes 0.722- \\
1.602\end{array}$ \\
\hline & $\mathrm{BMl}<19$ & 0.671 & $\begin{array}{l}0.799 \\
₫ 0.299- \\
1.299 \rrbracket\end{array}$ \\
\hline & $\mathrm{BMl}>24$ & 0.0216 & $\begin{array}{l}1.248 \\
\rrbracket 1.061- \\
1.527 \rrbracket\end{array}$ \\
\hline & $\begin{array}{l}\text { Abnormal coagulation function (decreased FIB or } \\
\text { increased PT/APTT) }\end{array}$ & 0.032 & $\begin{array}{l}2.545(1.412- \\
4.284)\end{array}$ \\
\hline & Preoperative $\mathrm{Hb}$ & 0.010 & 1.570 \\
\hline & $\leq 110 \mathrm{~g} / \mathrm{L}$ & & $1.904 \rrbracket$ \\
\hline & Preoperative platelet count $<150 / \mathrm{nL}$ & 0.106 & $\begin{array}{l}1.395 \\
\otimes 0.855- \\
1.935 \rrbracket\end{array}$ \\
\hline & $\begin{array}{l}\text { Complications (including diabetes, coronary heart } \\
\text { disease, hypertension and renal insufficiency) }\end{array}$ & 0.938 & $\begin{array}{l}0.985 \\
\otimes 0.635- \\
1.335 \rrbracket\end{array}$ \\
\hline & $\begin{array}{l}\text { Administration of antiplatelet drugs (e.g., aspirin, } \\
\text { clopidogrel) }\end{array}$ & 0.52 & $\begin{array}{l}1.14 \llbracket 0.210- \\
2.070 \rrbracket\end{array}$ \\
\hline & Multilevel lesions ( $\geq 2$ lumbar vertebrae) & 0.007 & $\begin{array}{l}3.911 \\
\bowtie 2.927- \\
4.687 \rrbracket\end{array}$ \\
\hline & Secondary operation of lumbar spine & 0.0054 & $\begin{array}{l}2.037 \\
\rrbracket 1.726- \\
2.616 \rrbracket\end{array}$ \\
\hline \multirow[t]{3}{*}{$\begin{array}{l}\text { Femoral } \\
\text { fracture }\end{array}$} & Age $>75$ & $3.593 \times 10^{-10}$ & $\begin{array}{l}2.175 \\
₫ 1.980- \\
2.287 \square\end{array}$ \\
\hline & Sex & 0.978 & $\begin{array}{l}1.005 \\
\otimes 0.065- \\
1.945 \rrbracket\end{array}$ \\
\hline & $\mathrm{BMl}<19$ & $7.508 \times 10^{-7}$ & $\begin{array}{l}2.099 \\
\bigotimes 1.691- \\
2.348 \rrbracket\end{array}$ \\
\hline
\end{tabular}


$\mathrm{BM}>24$

0.321

1.865

$\mathbb{8 0 . 8 7 5 -}$

2.855】

Abnormal coagulation function (FIB decreased or PT/APTT increased)

0.005

3.691

$\varangle 2.931$ -

$4.492 \rrbracket$

Preoperative $\mathrm{Hb}$

$1.119 \times 10^{-15}$

1.555

$\leq 110 \mathrm{~g} / \mathrm{L}$

1.7580

Preoperative platelet count $<150 / \mathrm{nL}$

0.106

1.395

$₫ 0.615-$

$2.175 \rrbracket$

Complications (including diabetes, coronary heart disease, hypertension and renal insufficiency)

0.874

1.037

$₫ 0.187-$

1.887ه

Administration of antiplatelet drugs (e.g., aspirin, clopidogrel)

0.0045

1.590

\$1.301-

1.815】

Femoral shaft fracture

0.007

3.011

\$1.929-

4.077》

Time from fracture to operation exceeding $48 \mathrm{~h}$

0.0370

1.220

\$1.046-

$1.394 \rrbracket$

$\mathrm{a} \otimes \mathrm{FIB}$-fibrinogen PT-prothrombin time APTT-activated partial thromboplastin time

Table 3. Predictive scoring system of allogeneic red blood cell transfusion during surgery 


\begin{tabular}{|c|c|c|c|c|}
\hline Disease & Risk factor & P-Value & $\begin{array}{l}\text { Odds ratio } \\
\text { } 95 \% \mathrm{Cl} \triangle\end{array}$ & Points \\
\hline \multirow[t]{7}{*}{$\begin{array}{l}\text { Lumbar spinal } \\
\text { stenosis }\end{array}$} & Age $>75$ & 0.00037 & $\begin{array}{l}1.63 \\
\otimes 1.473- \\
1.788 \rrbracket\end{array}$ & 1 \\
\hline & $\mathrm{BMl}>24$ & 0.0225 & 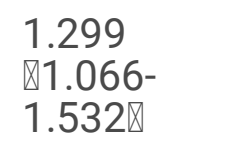 & 1 \\
\hline & $\begin{array}{l}\text { Abnormal coagulation function (FIB decreased } \\
\text { or PT/APTT increased) }\end{array}$ & 0.0466 & $\begin{array}{l}2.491 \\
\bigotimes 1.055- \\
3.927 \rrbracket\end{array}$ & 2 \\
\hline & Preoperative $\mathrm{Hb}$ & 0.000746 & 1.520 & 1 \\
\hline & $\leq 110 \mathrm{~g} / \mathrm{L}$ & & $1.877 \square$ & \\
\hline & Multilevel lesions ( $\geq 2$ lumbar vertebrae) & 0.01174 & $\begin{array}{l}3.508 \\
\rrbracket 2.628- \\
4.388 \rrbracket\end{array}$ & 3 \\
\hline & Secondary operation of lumbar spine & 0.00015 & 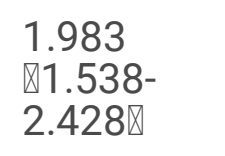 & 2 \\
\hline \multirow[t]{8}{*}{$\begin{array}{l}\text { Femoral } \\
\text { fracture }\end{array}$} & Age $>75$ & 0.00022 & $\begin{array}{l}1.974 \\
\bigotimes 1.821- \\
2.128 \rrbracket\end{array}$ & 2 \\
\hline & BMK $<19$ & 0.00008 & $\begin{array}{l}2.020 \\
\bigotimes 1.692- \\
2.349 \rrbracket\end{array}$ & 2 \\
\hline & $\begin{array}{l}\text { Abnormal coagulation function (FIB decreased } \\
\text { or PT/APTT increased) }\end{array}$ & 0.00462 & $\begin{array}{l}3.432 \\
\otimes 2.652- \\
4.213 \rrbracket\end{array}$ & 3 \\
\hline & Preoperative $\mathrm{Hb}$ & 0.000001 & 1.536 & 1 \\
\hline & $\leq 110 \mathrm{~g} / \mathrm{L}$ & & $1.738 \square$ & \\
\hline & $\begin{array}{l}\text { Take antiplatelet drugs (e.g., aspirin, } \\
\text { clopidogrel) }\end{array}$ & 0.0039 & 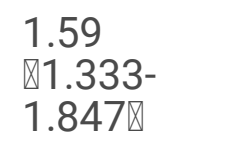 & 1 \\
\hline & Femoral shaft fracture & 0.004 & $\begin{array}{l}2.878 \\
\bigotimes 1.804- \\
3.952 \rrbracket\end{array}$ & 2 \\
\hline & $\begin{array}{l}\text { The time from fracture to operation exceeded } \\
48 \text { hours }\end{array}$ & 0.025 & $\begin{array}{l}1.294 \\
\otimes 1.115- \\
1.474 \rrbracket\end{array}$ & 1 \\
\hline
\end{tabular}

Table 4. Predicted score of intraoperative allogeneic red blood cell transfusion and actual blood use in aged patientsaged patients with lumbar spinal stenosis 


\begin{tabular}{|lllll|}
\hline Score & $\begin{array}{l}\text { Number of } \\
\text { patients }\end{array}$ & $\begin{array}{l}\text { Proportion of patients with } \\
\text { blood transfusions }\end{array}$ & $\begin{array}{l}\text { Average blood } \\
\text { transfusion } \\
\text { volume(U) }\end{array}$ & $\begin{array}{l}\text { Median blood } \\
\text { transfusion } \\
\text { volume(U) }\end{array}$ \\
\hline 0 & 50 & $28.0 \%$ & 0.5 & 0 \\
\hline 1 & 40 & $47.5 \%$ & 1.29 & 1 \\
\hline 2 & 189 & $59.8 \%$ & 1.78 & 2 \\
\hline 3 & 71 & $64.8 \%$ & 2.63 & 3 \\
\hline 4 & 116 & $68.1 \%$ & 2.46 & 3 \\
\hline 5 & 50 & $84.0 \%$ & 2.88 & 3 \\
\hline 6 & 39 & $82.1 \%$ & 3.12 & 3 \\
\hline 7 & 6 & $100 \%$ & 3.5 & 3.5 \\
\hline 8 & 1 & $100 \%$ & 4.00 & 4 \\
\hline 9 & 3 & $100 \%$ & 4.00 & - \\
\hline 10 & - & - & - & 4 \\
\hline
\end{tabular}

Table 5. Predicted score of intraoperative allogeneic red blood cell transfusion and actual blood use in aged patients with femoral fracture 


\begin{tabular}{|lllll|}
\hline Score & $\begin{array}{l}\text { Number of } \\
\text { patients }\end{array}$ & $\begin{array}{l}\text { Proportion of blood } \\
\text { transfusion }\end{array}$ & $\begin{array}{l}\text { Average blood } \\
\text { transfusion volume(U) }\end{array}$ & $\begin{array}{l}\text { Median blood } \\
\text { transfusion volume(U) }\end{array}$ \\
\hline 0 & 33 & $24.1 \%$ & 0.57 & 1 \\
\hline 1 & 181 & $42.6 \%$ & 1.80 & 2 \\
\hline 2 & 163 & $55.3 \%$ & 2.26 & 2 \\
\hline 3 & 106 & $60.9 \%$ & 2.43 & 3 \\
\hline 4 & 27 & $66.7 \%$ & 2.71 & 3 \\
\hline 5 & 33 & $72.8 \%$ & 3.28 & 3 \\
\hline 6 & 24 & $79.2 \%$ & 3.54 & 3 \\
\hline 7 & 12 & $83.3 \%$ & 3.79 & 4 \\
\hline 8 & 3 & $100 \%$ & 4.00 & 4 \\
\hline 9 & 1 & $100 \%$ & 4.00 & 4 \\
\hline 10 & 3 & $100 \%$ & 4.00 & - \\
\hline 11 & - & - & - & - \\
\hline 12 & - & - & - & 4 \\
\hline
\end{tabular}

Table 6. Comparison of predicted and actual proportion of blood transfusion and average blood transfusion volume in patients with lumbar spinal stenosis

\begin{tabular}{|lllllll|}
\hline Score & $\begin{array}{l}\text { Number } \\
\text { of } \\
\text { patients }\end{array}$ & $\begin{array}{l}\text { Predicted } \\
\text { proportion of } \\
\text { blood } \\
\text { transfusion }\end{array}$ & $\begin{array}{l}\text { Actual } \\
\text { proportion } \\
\text { of blood } \\
\text { transfusion }\end{array}$ & $\begin{array}{l}\text { Predicted } \\
\text { average blood } \\
\text { transfusion } \\
\text { volume (U) }\end{array}$ & $\begin{array}{l}\text { Actual } \\
\text { average blood } \\
\text { transfusion } \\
\text { volume (U) }\end{array}$ & $\begin{array}{l}\text { Median } \\
\text { blood } \\
\text { transfusion } \\
\text { volume(U) }\end{array}$ \\
\hline 0 & 15 & $24.4 \%$ & $26.7 \%$ & 0.29 & 0.50 & 0 \\
\hline 1 & 13 & $46.9 \%$ & $46.2 \%$ & 1.36 & 1.20 & 1 \\
\hline $2-3$ & 84 & $62.6 \%$ & $59.5 \%$ & 2.10 & 2.03 & 2 \\
\hline $7-6$ & 67 & $80.2 \%$ & $71.6 \%$ & 2.94 & 2.57 & 3 \\
\hline $7-10$ & 3 & $94.3 \%$ & $100.0 \%$ & 3.61 & 3.67 & 4 \\
\hline
\end{tabular}

Table 7. Comparison of predicted and actual proportion of blood transfusion and average blood transfusion volume in patients with femoral fracture 


\begin{tabular}{|lllllll|}
\hline Score & $\begin{array}{l}\text { Number } \\
\text { of } \\
\text { patients }\end{array}$ & $\begin{array}{l}\text { Predicted } \\
\text { proportion of } \\
\text { blood } \\
\text { transfusion }\end{array}$ & $\begin{array}{l}\text { Actual } \\
\text { proportion } \\
\text { of blood } \\
\text { transfusion }\end{array}$ & $\begin{array}{l}\text { Predicted } \\
\text { average blood } \\
\text { transfusion } \\
\text { volume (U) }\end{array}$ & $\begin{array}{l}\text { Actual } \\
\text { average blood } \\
\text { transfusion } \\
\text { volume (U) }\end{array}$ & $\begin{array}{l}\text { Median } \\
\text { blood } \\
\text { transfusion } \\
\text { volume(U) }\end{array}$ \\
\hline 0 & 11 & $22.3 \%$ & $27.3 \%$ & 0.62 & 0.67 & 1 \\
\hline $1-3$ & 149 & $52.2 \%$ & $51.0 \%$ & 2.08 & 1.95 & 2 \\
\hline $4-6$ & 28 & $67.7 \%$ & $71.4 \%$ & 2.82 & 3.13 & 3 \\
\hline $7-12$ & 6 & $89.6 \%$ & $83.3 \%$ & 3.77 & 3.67 & 4 \\
\hline
\end{tabular}

